\title{
Teaching Short Stories in the Omani Context: The Use of the Reader Response Theory
}

\author{
Yasmin Al-Bulushi \\ College of Banking and Financial Studies, Oman
}

\begin{abstract}
The present study investigated the effectiveness of using the Reader Response Theory (RRT) on Omani secondary school students' comprehension of short stories and their attitudes towards the method used in teaching short stories. To serve this purpose, two instruments were used in this study: a reading comprehension test and a questionnaire. The data obtained from the two instruments were analyzed using descriptive statistics and t- tests. Using the Semiexperimental method, the results showed that students who were taught a short story with the RRT did better on the comprehension test than those in the control groups. There was also a significant difference between the control and experimental group in their attitudes towards the method used in teaching and reading the short story and learning English in general in favor of the experimental group.
\end{abstract}

\section{Introduction}

Recent developments in teaching foreign languages stress learner-centered approaches. Literature teaching in language classroom has also been influenced by communicative language teaching [10] since it motivates students to continue language study and prepare them for the type of communication they would experience in the target culture [6] [2] [9]. One such approach, which has a growing influence on English as a Foreign Language (EFL) literature teaching, is the Reader-Response Theory (RRT).

\section{Literature Review}

The RRT is a theory of reading literary texts. In this theory, the reader plays an integral part in bringing meaning to the text, his thoughts, reactions and ideas analyzing and learning different aspects of literary texts [8].
Perhaps the best-known theorist to explicate Reader Response, as a pedagogical as well as critical stance, is Louise Rosenblatt [20][21], who formulated the "transactional theory" of reading and the distinction between "efferent" (utilitarian) and "aesthetic" reading. Roseblatt describes "aesthetic reading" as one that engages readers so that they live through the experience and, in so doing, recreates the text. The main aim of the RRT is to accept multiple interpretations to a text rather than just one correct interpretation [20][21][3][8.]. If this aim is important for native speakers, it is even more crucial for EFL/ESL students who need the added motivation to read literature in a foreign language.

RRT differs from the other approaches to the teaching of literature (e.g. Story Grammar and Focus Units) in that it does not stress the comprehension of the content of the text, rather the focus is on encouraging learners to respond to the text and express their ideas and feelings freely. Thus, the concern is not only on what you understand? But on how do you feel? [13] [23]. According to Sheridan [22] the reader must "invest themselves in the experience".

The Reader Response Theory supports communicative language teaching since it is rooted in a task-based methodology in which tasks designed are aimed to elicit the target language discourse production. What really makes the approach communicative is the intention of the tasks assigned by teachers in engaging learners in tasks, which require them to generate personal responses to something in the text, responses which necessitate the production of original discourse. This view allows room for creativity and reflective thinking in the literature classroom.

\subsection{Research on the Use of RRT in Teaching Literature}

Most of the research on the use of the RRT teaching English as a first language reported that designing instruction around RRT, helped students to 
understand challenging classics [4]. They came to a deeper understanding and appreciation of literary texts and learned more about their society and history [12] [24]. Students could exercise a great deal of creativity in making sense of literary texts [25] and there were more co-operative attitudes in the group work and students enjoyed reading classics [5] [23].

\subsection{Research on the Use of RRT in EFL/ESL Classrooms}

Most research conducted in EFL/ESL context has indicated that the students enjoyed been given the opportunity to express their own thoughts and feelings [2] [9]. Some studies reported that students gained clearer understanding of the ideas in the literary texts [6] and the approach allowed brining a lot of cultural concepts to their interpretations of literary texts [19].

Most studies on the use of RRT have not attempted to use a comprehension test as an instrument for measuring learners' comprehension after being exposed to the RRT. However, some studies found that some activities used helped the students in improving their reading and writing skills [6] and they came to a clear understanding and deeper appreciation of the literary text [24].

\subsection{Activities Used in the RRT}

A number of different classroom activities using the RRT have been put forward: Response logs/ journals [15] [17] [22], response questions [13] [23] and response forms [1]. Elliot [9] \& Baxter [4] used role-play, drama, and creative writing in conjunction with texts. Oster [16] assigned writing tasks, which require students to shift point of view in a given story or in a story of their own. McEneaney et al. [14.] assigned writing tasks to examine students' recall and understanding of expository hypertext. Totten [24] Probst [18] \& Henly [12] designed frame-works which were used as Teacher's manual in teaching literary texts to their students.

\section{Teaching Short Stories in Oman}

In the Omani context, where English is considered as a foreign language with Arabic being the language spoken at home, teaching short stories are the only form of literature taught in the English language classes (EFL) at school level. Students in the seventh and eighth grades (12-13 years old) are supposed to read six readers (short stories) a year. Teachers are given a set of guidelines to teach these readers. These guidelines follow the story grammar approach. In the other grades - from the ninth to the twelfth (14-18 years old) - there are no guidelines for teaching short stories. Informal interviews by the researcher with some Omani teachers of English in secondary schools in Muscat, revealed that there are no agreed upon strategies for teaching stories. Teachers indicated that their main concern was to enable students to retain the content of the story. Thus the present study sought to addresses the following questions:

- What is the effect of the RRT on the second year secondary Omani students' comprehension of short stories?

- What are the second year secondary Omani students' attitudes towards the method used in teaching short stories?

\section{The Current study}

\subsection{Population and sample}

The population of the study consisted of all second year secondary school female students in the Muscat Region $(\mathrm{N}=2137)$. Since it is a quasi-experimental research, the researcher decided to conduct it in one school in Muscat region. This school was and two classes were randomly. One class functioned as a 'control group' $(\mathrm{N}=\mathbf{2 9})$ and the other as 'experimental group' $(\mathrm{N}=\mathbf{2 8})$. The choice of the school in the Muscat Region was for reasons of convenience as it is the capital area, which as the researcher believed has all the characteristics of Omani society. Moreover, the choice of female schools was because all the secondary schools in Oman are sex segregated and the researcher felt that conducting the experiment in a male school might be culturally inappropriate and inconvenient for the teachers and the researcher.

\subsection{Research Instruments and Materials}

Two instruments were used in this study: a reading comprehension test and a questionnaire.

The questionnaire was used to elicit student's attitudes towards the method used in teaching the story. Taking into consideration students' level in English the questionnaire was translated into Arabic to eliminate any possibilities of misunderstanding and 
miscomprehension of the items. The test consisted of five questions. The researcher designed the comprehension questions based on the classifications of reading comprehension tasks or questioning presented in Harmer [11] and Choate et al. [7]. The tasks were classified to: reading to confirm expectation reading to extract specific information, reading for communicative and reading for detailed comprehension. The last question of the reading test was a "story frame". The researcher believed that one goal of the RRT is to enable students to gain sight in the inner structure of the story. It aimed at measuring students' global comprehension of the story.

Both instruments were validated by a group of specialists in EFL from Sultan Qaboos University (Oman) and a group of practitioners from the Ministry of Education. The items of the questionnaire were validated with reference to: relevance, importance and clarity of the items. The comprehension test was validated in terms of clarity, difficulty and appropriateness of these questions in terms of grammar and vocabulary. The test-retest reliability of the comprehension test yielded a coefficient of about 0.93; And the Alpha coefficient of the questionnaire was 0.94. Both the test and the questionnaire were administered at the end of the experiment.

\subsection{Research Procedures}

The main steps followed in the designing of instruments and materials were: designing a teacher's manual based on the RRT to be used with the experimental group in teaching them the short story. Next, administering the questionnaire to both the experimental and control group. Finally, administrating the reading comprehension test to both groups.

The researcher spent two months visiting the school and teaching the story to the experimental group once a week. The control group was taught by one of school teacher. This was done to avoid the influence of RRT on the researcher's performance in the control group. The researcher, however, observed the control group regularly.

The researcher followed these steps in implementing the teacher's manual: Students were briefed about their groups and roles, they were informed to read each episode at home, and were asked to keep a notebook, to serve as a response journal. The teacher instructed the students on how/what to write in their notebooks. The researcher wrote the following questions on the board to guide the students in writing their comments on the episodes.
While you are reading each episode at home write down all the things that go on in your head. What questions you ask yourself about the characters and the events as you read? What memories, from your own experience, were provoked by the text? Write down your thoughts and feelings about the characters or events? Any comments on the episode?

After the first instruction on how and what to write in their notebooks, notebooks were assigned as individual homework. The teacher collected these notebooks after each lesson and read them. The teacher commented on them but did NOT correct them. The purpose of this activity was just to know the students' reactions towards the story. Moreover, at the beginning of each lesson the teacher asked one or two students to read aloud their comments on the episode. This served as a check on their comprehension of English, and it set the context of group discussion.

The researcher utilized The Swiss Family Robinson by Wyss [26] because students have to read the story as part of the English syllabus. It is a short story consisting of (20) chapters. These chapters were divided into (9) episodes (Table 1). This was arranged so that the researcher will be able to finish teaching the experimental group in nine weeks. Table (1) shows that:

Table 1. The Distribution of the 20 chapters to 9 episodes

\begin{tabular}{|l|l|}
\hline The episode & The chapter(s) \\
\hline Episode 1 & Chapters $(1+2)$ \\
\hline Episode 2 & Chapters $(3+4)$ \\
\hline Episode 3 & Chapters $(5+6+7)$ \\
\hline Episode 4 & Chapters $(8+9)$ \\
\hline Episode 5 & Chapters $(10+11)$ \\
\hline Episode 6 & Chapters $(12+13)$ \\
\hline Episode 7 & Chapter $(14+15)$ \\
\hline Episode 8 & Chapters $(16+17+18)$ \\
\hline Episode 9 & Chapters $(19+20)$ \\
\hline
\end{tabular}

The same steps were followed in the control group except that the teaching was conducted differently. In the lesson, the teacher discussed the story with the students (characters, events), wrote a set of comprehension questions on board and asked the students to read the story silently and answer these questions in their exercise book. The teacher, then, discussed the answers with the students. 


\section{Analysis of Findings}

The data obtained from the two instruments was subjected to different statistical techniques, namely descriptive statistics and t-test.

The comprehension test data was analyzed by means of calculating the means and t-test as shown in Table (2).

Table 2. Test results of the sample's scores on the reading comprehension test

\begin{tabular}{|c|c|c|c|c|c|c|}
\hline Variable & \multicolumn{2}{|c|}{$\begin{array}{c}\text { Experimental } \\
\text { Group }\end{array}$} & \multicolumn{2}{|c|}{$\begin{array}{c}\text { Control } \\
\text { Group }\end{array}$} & \multirow{2}{*}{$\begin{array}{c}\text { T } \\
\text { value }\end{array}$} & $\begin{array}{c}\text { Sig. } \\
\text { (2-tailed) }\end{array}$ \\
\cline { 2 - 5 } & Mean & SD & Mean & SD & & \\
\hline Scores & 19.14 & 5.20 & 15.45 & 6.51 & 2.31 & .05 \\
\hline
\end{tabular}

Table (2) shows that there was a statistically significant difference between the mean score of the two groups at .05 , in fever of the experimental group. This reveals that there was a positive effect of the RRT, used in teaching the story to the experimental group, on students' comprehension of the stories. This supported the findings of previous studies in this field.

For the questionnaire, the participants in both the experimental and control groups were asked to rate 34 items on a 5-point Likert scale. The items were classified into two main categories:

- The effect of the method used in teaching short stories on students attitudes towards reading short stories in English.

- The effect of the method used in teaching short stories on students attitudes towards learning English language in general.

Table 3 shows these results.

Table 2. T-test results of the sample's responses to the two main categories of the attitude's questionnaire

\begin{tabular}{|c|l|l|l|l|l|l|}
\hline Variable & \multicolumn{2}{|c|}{$\begin{array}{c}\text { Experimental } \\
\text { Group }\end{array}$} & \multicolumn{2}{c|}{$\begin{array}{c}\text { Control } \\
\text { Group }\end{array}$} & \multirow{2}{T}{$\begin{array}{c}\text { T } \\
\text { value }\end{array}$} & $\begin{array}{c}\text { Sig. } \\
\text { (2-tailed) }\end{array}$ \\
\cline { 2 - 5 } & Mean & SD & Mean & SD & & \\
\hline Story & 3.73 & .63 & 2.80 & .74 & 5.095 & .001 \\
\hline Language & 3.96 & .71 & 3.19 & .72 & 4.063 & .001 \\
\hline
\end{tabular}

As Table 3 indicates, the students in both groups differed significantly in their responses to the two categories of the questionnaire. The differences were in favor of the experimental group, that is, the students in the experimental group were significantly more satisfied and held more positive attitudes toward reading short stories in English and learning English in general than the control group. This was more obvious when students' responses in both groups were analyzed for each category.

T-test was used to indicate the differences between the two groups in their attitudes towards reading short stories in English according to the sub-categories. Table 4 shows these results:

Table 3. T-test results of the sample's responses to the five sub-categories of the first main category

\begin{tabular}{|c|c|c|c|c|c|c|}
\hline \multirow[t]{2}{*}{ Sub-categories } & \multicolumn{2}{|c|}{$\begin{array}{l}\text { Experimental } \\
\text { group }\end{array}$} & \multicolumn{2}{|c|}{ Control group } & \multirow{2}{*}{$\begin{array}{l}\mathrm{T} \\
\text { value }\end{array}$} & \multirow{2}{*}{$\begin{array}{l}\text { Sig. } \\
\text { (2-tailed) }\end{array}$} \\
\hline & Mean & SD & Mean & $\mathrm{SD}$ & & \\
\hline Critical thinking & 3.89 & .71 & 2.85 & .86 & 5.014 & .001 \\
\hline Prior knowledge & 4.29 & .89 & 3.52 & 1.27 & 2.645 & .01 \\
\hline Expressing Opinion & 4.13 & .73 & 3.19 & .94 & 4.210 & .001 \\
\hline Motivation & 3.53 & .67 & 2.67 & .94 & 4.000 & .001 \\
\hline Pleasure reading & 3.54 & .95 & 2.63 & .94 & 3.617 & .001 \\
\hline
\end{tabular}

The students in the experimental group think that the RRT helped them to think critically about the characters and events and "live with the characters". They also reported that the RRT helped them to activate their prior knowledge and improved their imagination through the different situations in the story. Majority of the students in the experimental group agreed that the RRT helped them to express their opinions about the different aspect of the story freely.

In the control group, on the other hand, very few students agreed that the traditional method gave them this opportunity.

The participants in the experimental group indicated that RRT made them enjoy reading English stories. The participants in the control group, compared to the experimental group, had negative attitudes towards reading short stories. T-test was used to find out the differences between the two groups in their attitudes towards learning English language in general.

Table 4. T-test results of the sample's responses to the four sub-categories of the second main category

\begin{tabular}{|c|c|c|c|c|c|c|}
\hline \multirow[t]{2}{*}{ Sub-categories } & \multicolumn{2}{|c|}{$\begin{array}{l}\text { Experimental } \\
\text { group }\end{array}$} & \multicolumn{2}{|c|}{ Control group } & \multirow[t]{2}{*}{ T value } & \multirow[t]{2}{*}{$\begin{array}{l}\text { Sig. } \\
\text { (2-tailed) }\end{array}$} \\
\hline & Mean & SD & Mean & SD & & \\
\hline Skills & 4.01 & .97 & 3.34 & .88 & 2.723 & .01 \\
\hline English classes & 4.01 & .86 & 3.23 & .84 & 3.485 & .001 \\
\hline Beliefs & 4.04 & .80 & 2.91 & 1.07 & 4.486 & .001 \\
\hline $\begin{array}{l}\text { Extra-curricular } \\
\text { activities }\end{array}$ & 3.66 & .78 & 3.02 & 1.03 & 2.661 & .01 \\
\hline
\end{tabular}


In this sub-category where the students were asked whether the method made them acquire both the skills of reading and writing in English, the participants in the experimental group significantly indicated relatively more positive responses than the control group. Furthermore, RRT is rooted in a task-based methodology in which tasks are aimed at eliciting target language discourse production. This in turn helped them to develop their reading, writing, and speaking skills.

Majority of the students in the experimental group indicated that the RRT made them enjoy English lessons/classes more compared to the control group. The majority of the students in the experimental group agreed that the RRT changed their wrong beliefs about English language. This might be because the students in the experimental group were encouraged to use English freely (both in speaking and writing). The RRT's tasks were designed in a way that encourages the students to make responses even if they do not use the target language (e.g. drawing). In addition, the researcher encouraged these students to keep response journal, for which the researcher assured the students that she was not going to mark these journals or comment on them.

The researcher analyzed students' response journal and noticed students' behavior and attitudes in the classrooms. These analyses revealed the following:

1. Through the RRT the students began to make personal connections between literature and their lives and the world.

2. Through the classroom discussion, students learn to accept other students' opinions and interpretations.

3. The tasks asking the students to react to different characters provided an excellent opportunity for the discussion of characters. Students were eager to justify why they had reacted in certain ways towards the characters.

4. The tasks allowed the students to discuss and write about issues that interested them. Students gained insight about other societies and cultures. Moreover, students reported that they gained clearer understanding of the ideas in the story.

5. Students who wrote extensively in response journals did significantly better in interpretation questions and generalization questions than the others.

\section{Contribution to knowledge}

The present study demonstrated that there was a positive effect of RRT on students' attitudes and comprehension. This suggests that teachers and curriculum designers should perhaps use more students-centered methods of teaching that foster critical awareness in students and help them become more autonomous learners.

Literary texts, therefore, must not be reduced to exercises or drill, but must be allowed to live as a work of art, influencing the reader to see, think, feel and reflect. Finally, curriculum designers should guide teachers into using more students-centered methods in the classroom and should encourage teachers into designing and using their own materials, which may better suit their students. EFL teachers should be trained to use the RRT in teaching short stories. Workshops may be organized by the Ministry of Education and the In-Service Training Department.

\section{Future Work}

This research was limited to only two second secondary science students' classes in the capital area of Oman. It is therefore suggested that a study like this be carried out on a larger scale (beyond the Muscat boundaries). Further research of this kind could involve other academic levels (preparatory, elementary). It is also suggested that a study like this one to be extended to include other activities using RRT (e.g. role play, drama). Finally, more research needs to be carried out into the nature of RRT in EFL learning and how teaching methods affect this. A lot of research of this kind seems to have been done in teaching English as the first language (L1). Such studies would definitely benefit the teaching in the EFL classrooms.

\section{References}

[1] Akrofi, A., Janisch, C., Button, K. \& Liu, X. "Catch a Star Book! Responses of Fifth-Grade Students to CelebrityAuthored Children's Literature”. Literacy Research and Instruction, 2010, 49: 142-161.

[2] Ali, S. "The reader-response approach: An alternative for teaching literature in a second language”. Journal of Reading, 1994, 37 (4): 288-296.

[3] Atkinson, B. "Teachers Responding to Narrative Inquiry: An Approach to Narrative Inquiry Criticism". Journal of Educational Research, 2010, 103: 91-102.

[4] Baxter, Judith. "A Message from the Old World to the New: Teaching Classic Fiction through Drama”, English Journal, 1999, 89(2): 120-124. 
[5] Canterford, B. "Cultivating the Growth of Reader Response”. English in Australia, 1986, 75: 50-58.

[6] Carlisle, A. "Reading logs: An Application of ReaderResponse Theory in ELT”. ELT Journal, 2000, 54(1): 12-19.

[7] Choate, E., Miller, P. \& Rakes. Curriculum-Based assessment and programming ( $3^{\text {rd }}$ ed), Allyn and Bacon. U.S.A.,1995.

[8] Connell, J. “The Emergence of Pragmatic Philosophy's Influence on Literary Theory: Making Meaning with Texts from a Transactional Perspective". Educational Theory, 2008, 58(1):103-122.

[9] Elliot, R. "Encouraging Reader-Response to Literature in ESL Situation”. ELT Journal, 1990, 44(3): 191-198.

[10] Gilroy, M. \& Parkinson, B. "Teaching Literature in a Foreign Language”. Language Teaching, 1997, 29: 213-225.

[11] Harmer, J. The Practice of English Language Teaching (New Edition), Longman Publishing, New York, 1999.

[12] Henly, C. "Reader-Response Theory as Antidote to Controversy: Teaching the Bluest Eye”. English Journal, 1993, 82(3): 13-19.

[13] Hirvela, A. "Reader-Response Theory and ELT". ELT Journal, 1996, 50(2): 127-134.

[14] McEneaney, J., Li, L., Allen, K. and Guzniczak, L. "Stance, Navigation, and Reader Response in Expository Hypertext”. Journal of Literacy Research, 2009, 41: 1-45.

[15] McRae, M. "Turning Reader-Response Theory into Student-Centered Classroom Practice”. Exercise Exchange, 1986, 31(2): 21-23.

[16] Oster, J. "Seeing with different eyes: Another View of Literature in the ESL Class”. TESOL Quarterly, 1989, 23: 85-103.

[17] Pritchard, R. "Developing Writing Prompts for Reading Response and Analysis”. English Journal, 1993, 82(3): 2432.

[18] Probst, E. "Reader-Response Theory and the English Curriculum”. English Journal, 1994, 83(3): 37-44.

[19] Poyas, Y. "Exploring the Horizons of the Literature Classroom-Reader Response, Reception Theories and Classroom Discourse”. L1-Educational Studies in language and Literature, 2004, 4:63-84.

[20] Rosenblatt, L. Literature as Exploration (5 ${ }^{\text {th }}$ ed.), The Modern Language Association, New York, 1995.
[21] Rosenblatt, L. "The Transactional Model of Reading and Writing” In Ruddell, R., Ruddell, M. and Singer, H. (Eds) Theoretical Models and Processes of Reading (PP.13631398). Newwark, DE: IRA, 2004.

[22] Sheridan, D. "Changing Business as usual: Reader Response in the Classroom”. College English, 1991, 53(7): 804-814.

[23] Spiegel, D. L. "Reader Response Approaches and the Growth of Readers”. Language Arts, 1998, 76(1): 41-48.

[24] Tottan, S. "Using Reader-Response Theory to Study Poetry about Holocaust with High School Students". The Social Studies, 1998, 89(1): 30-34.

[25] Wiegand, W.A. "Out of Sight, Out of Mind: Why Don’t We Have Any Schools of Library and Reading Studies?" Journal of Education for Library and Information Science, 1997, 38(4): 314-325.

[26] Wyss, Johann. The Swiss Family Robinson. Penguin Longman Publishing, UK, 2000. 